\title{
TEACHING READING COMPREHENSION USING GROUP DISCUSSION
}

\author{
Muhamad Rizwan', Cynantia Rachmijati ${ }^{2}$ \\ 1,2 IKIP Siliwangi \\ ${ }^{1}$ muhrizwan@student.ikipsiliwangi.ac.id, ${ }^{2}$ cynantia@yandex.com
}

\begin{abstract}
English as the first foreign language in Indonesia has important learn. Some aspects in leaning English cover listening, speaking reading and writing. All aspects are crucial for learners to be mastered thus, reading can be the essential aspect of all. In English reading, the difficulties that occur during the lesson is the activity. It is necessary for teachers to establish a good reading activity to cover the teaching and learning activity. The author implemented group discussion to answer the problem in reading activity. The research is established by quantitative method quasi experimental design with pre test and posttest as the instrument of the research. The population is seventh grade students of SMP Negeri 4 CikalongWetan and the sample is 30 students of $7 \mathrm{~A}$ as experiment class and 30 students of $7 \mathrm{~B}$ as control class. The data collected is analyzed by SPSS using Mann Whitney U test with 0.05 level of significance. The result shows value of significance is 0.010 which is less than 0.05 coefficient level $(0.010<0.05)$ which shows that the null hypothesis is rejected. In conclusion, there is significant difference between students' reading comprehension in both class.
\end{abstract}

Keywords: Group Discussion, Reading Comprehension

\section{INTRODUCTION}

English a compulsory subject, has become crucial subject to be examined in a national examination. It is focused on four language skills where reading comprehension becomes the primary intention of learning. In achieving the objective of reading, the process of teaching reading is required. Teaching reading is a process of acquiring knowledge in classroom activity held by the a teacher and the students. The teacher take responsibility to maintain classroom reading activity to attain the objective of learnig reading comprehension. They have to enable the students to comprehend the reading text. Furthermore, They have to manage a good reading activity to give the learners opportunity to learn reading with full motivation, focus, and interest.

Reading comprehension is an activity of getting informations from the reading text. Walter ( 2004) as cited in (Sumiati et al., 2019)Reading comprehension is an acivity of getting information by the readers towards the text they have read. In this activity, the readers interact with the text and expect the whole information from the text. According to Gibbon (1993:51) as cited in (Indah, 2018) stated that reading is the process of getting meaning from print. It compromises that reading is an activity to get information from the written text. In this activity, the author communicates with the readers through the reading text. This communication is enable the readers to get the knowledge from the author. By reading activity, the readers are able to get knowledge from the author. It is clearly to say that reading is not passive activity. When people read, they get some information which means they acquire reading comprehension ability. Nunan (1989: 33) as cited in (Rahmat, 2017) stated Reading is an active and interactive activity to reproduce the word mentally and vocally and tries to understand the content of reading text. While according to Harmer in (Izefti, 2018) said that there are some 
skills in reading: firstly, analyzing the topic; proper readers can spot the topic from the text immediately. Secondly, predicting and guessing; in understanding the text, readers normally predict the text especially when they have got the topic to understand the context. Then, reading for general understanding; proper readers can go with the flow of text and get the meaning of it without getting stressed about the particular information; in contrast for reading for gist, reading in frequent is required to get the detail information from the text. Lastly,interpreting text; readers can acquire the meaning from the text, digest in mind and transform the whole text into knowledge.

In the classroom, reading comprehension has to be taught by an appropriate method in order to achieve the learning objectives. One of appropriates method is group discussion. According to Djamarah (2006) as cited in (Ningsih, 2018) small group discussion is learning method enable students to be more active by interacting with their class mates. Arends (1997: 200) as cited in (Arise, 2018) said Small Group Discussion method is One of techniques that can be implemented by teacher especially to teach reading. Furthermore, Slavin in (Arise, 2018) stated that Cooperativelearning methods, students work jointly in group of four to master material originally delivered by the teacher. From some definitions above it can be inferred that group discussion as cooperative learning method can be an appropriate way in teaching reading comprehension.

The classroom management in establishing group discussion is essential for teacher to maintain the students to be able to engage with the activity. Nunan, (1989: 91) in (Rahmat, 2017) stated that the classroom organization does not deal directly with the reading process, or with materials, methods, or approaches to teaching reading comprehension. Yet without good classroom organization and classroom management, reading instruction may be totally ineffective.

According to Jennifer (2010) as cited in (Indah, 2018) there are three steps that can help teacher in teaching reading by using small group discussion technique in class room activities:

\section{1) Pre-discussion activities}

The teacher conveyed the topics to be discussed for example narrative text. The teacher provided a short explanation about the narrative text as well as gave an example. So in this class the teacher guided the students to discuss the narrative exercises in group.

2) Whilst discussion activities

The teacher instructed the students to begin reading text and answered the question in each group. The teacher and students were in the interactive learning activity. The students were active to ask a question, and the teacher gave responses to make it clear

\section{3) Post discussion activities}

The teacher collected the worksheets of each groups. Then she clarified the students result. But she was not asking some oral questions to member of groups because of the timing of the reading class is finished.

By following the steps above, teachers can maintain the implementation of group discussion properly in the classroom to achieve the objective of learning and to get the students engaged with the activity. The group discussion method can be a good method in teaching reading 
comprehension due to its benefits. Sagala (2008: 20) as cited in (Putri et al., 2014) says that group discussion is more effective if the group consisted of 3-4 students; enable students to give their opinions or ideas to other students easily. In a group, the students are free to talk and to discuss the solution to answer the questions because they do not accomplish their tasks individually.

Meanwhile, (Arisman \& Haryanti, 2019) stated that the positive primary aspect of using group discussion is the students can share to each other to solve the problem it needs good teamwork. They need to share their idea and discuss the way to fix it. Furthermore, (Arisman \& Haryanti, 2019) cited the benefits of impelementing group discussion in the classroom as follows:

a) Improves students' learning in cognitive and affective aspect.

b) students-centered learning.

c) trigger students' critical thinking to solve the problem.

d) boost students to engage with experience exchange and to make active learning

e) Provides the students in sharing ideas.

f) gives positive support of interpersonal ability.

g) build up the comprehension from previous learning.

h) developing ideas.

i) Sharing ideas.

\section{METHOD}

In establishing this research, the writer applies quantitative method with quasi-experimental design. According to Mc Millian \& Schumacher (2000) in (Amal \& Sadikin, 2018) quantitative method emphasizes a priori category to collect data in the form of numbers. The goal is to provide statistical descriptions, relationships, and explanations. Meanwhile, Kaswan (2016) in (Payumi \& Hartati, 2018) argues quasi-experimental design, or sometimes called naturally occurring group design, are similar to the true experimental design except that the writer makes comparisons between mean scores of the groups that occur naturally. The writer first gave the pre test towards both experimental and control group to get the basic information of students' achievement. Then, the treatment is given to the experiment group by applying group discussion method while the control group is being treated by traditional method or teacher-centered method. After that, the writer gives rthe post test to the groups for further analysis. The writer chose seventh grader students of SMPN 4 Cikalongwetan in the academic year 2019/2020 as the population, while the sample of the research are the class seventh A as experiment class and class seventh B as control class. The data is acquired by giving the sample the tests they are pre test and post test. The data analysis is done in SPSS by doing mann whitney test.

\section{RESULTS AND DISCUSSION}

\section{Results}

From the calculated scores, the writer got total score $\left(\sum\right)$ and Mean $(\bar{x})$ value of both experiment and control class.

Table.1 Students' score of experiment class

Experiment Class 


\begin{tabular}{ccc}
\hline Test & Pre Test & Post tes \\
\hline $\mathrm{N}$ & 35 & 35 \\
\hline $\begin{array}{c}\text { Max } \\
\text { score }\end{array}$ & 95 & 95 \\
\hline $\begin{array}{c}\text { Min } \\
\text { Score }\end{array}$ & 35 & 55 \\
\hline $\begin{array}{c}\text { Total } \\
\text { Score }\end{array}$ & 2495 & 2715 \\
\hline Mean $\bar{x}$ & 71.5 & 77.5 \\
\hline
\end{tabular}

Based on the table above, the total score of pre test is 2495 and the total post test score is 2715. The mean value of pre test is 71.5 and the posttest is 75.5 . The maximum score is 95 in pre test and 95 in post test. Based on the comparison of total score and mean score above, the students' acvievement improved.

Table.2 Students' Score of Control Class

\section{Control Class}

\begin{tabular}{ccc}
\hline 'Test & Pre Test & Post tes \\
\hline $\mathrm{N}$ & 35 & 35 \\
\hline Max score & 70 & 80 \\
\hline Min Score & 45 & 55 \\
\hline $\begin{array}{c}\text { Total } \\
\text { Score }\end{array}$ & 2125 & 2235 \\
\hline Mean $\bar{x}$ & 62.5 & 68.5 \\
\hline
\end{tabular}

The table shows that the total value of pre test score in control class is 1862 while the total post test score is 2067 . The maximum point of pre test is 75 and post test 85 while the minimum point in pretest is 50 and posttest is 55. The Mean score of pretest score is 62.1 while the Mean score of post test is 68.9. From the data analysis, students' achievement in reading skill improved. Meanwhile, the data indicates that the improvement value is low by comparing the mean score of the tests. It indicates that the group without group discussion was impelemnted doesn't show significant improvement.

Table 3

Data Statistic 


\begin{tabular}{|c|c|c|c|c|c|}
\hline pretest experiment & 35 & 35 & 95 & 71.5 & 8,285 \\
\hline posttest experiment & 35 & 55 & 95 & 77.5 & 6,303 \\
\hline pretest control & 35 & 45 & 70 & 62,5 & 8,389 \\
\hline posttest control & 35 & 55 & 80 & 68,5 & 8,669 \\
\hline valid N (listwise) & 35 & & & & \\
\hline
\end{tabular}

The table shows that the value of pretest of the experiment class is lower than control class while the value of posttest in the experiment is higher than controlclass. It can be inferred that group that group discussion is implementd gets better achievement than the group which did not.

\section{Normailty Test}

Normality test was done to determine the normality of the data distribution. The table below is the normality test result by using Kolmogorov-Smirnov test on SPSS Ver.19

Table 4

Normality Test

\begin{tabular}{lrrrrrr}
\hline & \multicolumn{3}{c}{ kolmogorov-smirnov $^{\text {a }}$} & \multicolumn{3}{c}{ Shapiro-Wilk } \\
\cline { 2 - 8 } & Statistic & df & \multicolumn{1}{c}{ Sig. } & Statistic & df & \multicolumn{1}{c}{ Sig. } \\
\hline Experiment & .149 & 30 & .025 & .955 & 30 & .088 \\
\hline Control & .180 & 30 & .014 & .934 & 30 & .065 \\
\hline
\end{tabular}

The result is 0.025 for experiment class and 0.014 for control class which indicates that the data distribution is not normal. It is done by comparing to the coefficient value 0.05 which showed both experiment class and control class are less than 0.05 value of coefficient.

\section{Non Parametric Mann Whitney $U$ test}

After calculating the mean score of both groups, the test is continued by comparing the significant difference of achievement in reading comprehension between experiment class and control class. The test is done by using Mann Whitney U test in SPSS ver.16

Table 3 Mann Whitney Test

\begin{tabular}{|c|c|c|c|c|}
\hline \multicolumn{5}{|c|}{ Ranks } \\
\hline & class & $\mathrm{N}$ & Mean Rank & Sum of Ranks \\
\hline \multirow{3}{*}{$\begin{array}{l}\text { Group_discus } \\
\text { sion }\end{array}$} & 1 & 35 & 36.22 & 1086.50 \\
\hline & 2 & 35 & 24.78 & 743.50 \\
\hline & Total & 70 & & \\
\hline
\end{tabular}




\begin{tabular}{lr}
\hline \multicolumn{2}{c}{ Test Statistics $^{\mathbf{a}}$} \\
\hline \multicolumn{3}{c}{ Group discussion_method $^{2}$} & 278.500 \\
\hline Mann-Whitney & \\
\hline Wilcoxon W & 743.500 \\
\hline$Z$ & -2.589 \\
\hline Asymp. Sig. (2- & .010 \\
tailed) & \\
\hline
\end{tabular}

a. Grouping Variable: class

Based on the table above, the data presents the Sig. (2-tailed) score of post test is 0.010 which less than 0.05 level of significance. Regarding to the value, the null hypothesis $H o$ is rejected because the Sig. (2-tailed) score of $0.010<0.05$ which represents the significant difference of achievement between the students in both groups increased after post test. The Mean rank experimen group is 36.22 higher than Mean rank of controlclass which is 24.78 . according to the data, the experimnt class achieved better result.

\section{Discussion}

After analyzing the data, the discussion of how group discussion method can improve students' reading skill was elaborated based on the discussion. The research finding implies that group discussion method improved students' reading comprehension skill by comparing the posttest average rank of both groups. The posttest rank of experment class was 77.5 while the average rank of control group was 68.5 which implies the experiment group got higher score than control group $(77.5>68.5)$.

The normality result indicates that the data distribution was not normal. So, for further calculation the writer used non parametric test using Mann Whitney $U$ test with IBM SPSS version 19. The result of equality variances test implies that the sig.2 tailed score is 0.010 less than rank of significance 0.05 , thus the null hypothesis is rejected. It is clear to say that students' comprehension in reading in experiment group improved. According to the result, group discussion method can improve students' reading comprehension ability. As a method of learning, group discussion is effective to build up learners' reading comprehension ability.

\section{CONCLUSION}

In learning English, reading is a very crucial aspect that should be mastered to communicate properly. Teachers must maintain an appropriate teaching method . By creating an enjoyable learning process, students' could gain their achievement towards the materials.. Hence, the objective of teaching reading can be achived maximally. The result of the data analysis indicates that experiment group score is 77.5 and control class got 68.5 on the mean rank. Based on the result, the (Ho) is rejected because the P-value of Mann Whitney $\mathrm{U}$ test $=0.010$ which is less than significant level 0.05 it means Ho : x $1>$ x 2 is rejected. It also implies that group discussion was successful to build up students' reading comprehension ability. Group discussion method 
made students enjoy the process of learning especially in reading activity. It allowed students to engange actively in their learning process. It also develops students' interest and motivation towards their reading activity. In reading activity, group discussion method helped students to understand the text.

\section{ACKNOWLEDGMENTS}

Alhamdulillahirabbil'alamin. First of all, I always thank to Allah because the writer finally finish this article. This article could not be completed without a great deal of help from many people, especially Mrs. Cynantia Rachmijati as an advisor who has provided invaluable for the guidance, patient, kindness, contribution, correcting, and helping me in finishing this journal. Without his guidance this article would not be completed well. Then for Mrs. Aseptiana Parmawati, M. Pd., who helped me from submitting to publishing this journal.

\section{REFERENCES}

Amal, F. A. T., \& Sadikin, I. S. (2018). Improving Students 'Reading Comprehension through Small Group Work Technique at the Seventh Grade Students of SMP Rosa Jaya. 1(2), 6370.

Arisman, R., \& Haryanti, I. S. (2019). Using Small Group Discussion To Improve Students' Reading Achievement on Narrative Text. English Community Journal, 3(1), 325. https://doi.org/10.32502/ecj.v3i1.1698

Aulia, R. I. (2014). The effect of small group discussion toward eighth graders reading comprehension. Study on the Group Discussion-Based English Reading Teaching, 7(1), 102-106.

Darise, N. (2018). The Effectiveness of Small Group Discussion Method in The Teaching of Reading Comprehension To The Second Grade Students of State Senior High School (SMA Negeri) 3 South Sinjai (Doctoral dissertation, Universitas Islam Negeri Alauddin Makassar).

Indah, N. (2018). Using Small Group Discussion Technique in Teaching Reading Comprehension (A Study at SMAN 1 Darul Makmur) (Doctoral dissertation, UIN ArRaniry Banda Aceh).

Ningsih, N. (2018). Small Group Discussion Method in Teaching Reading Comprehension in Eight Grade Students of Smp N 3 Bantul in Academic Year 2017 /2018. 05, 1.

Payumi, C. M., \& Hartati, Y. F. (2018). the Use of Close Reading Technique To Improve Students Reading Comprehension. PROJECT (Professional Journal of English Education), 1(3), 187. https://doi.org/10.22460/project.v1i3.p187-194

Putri, Y., Suparman, U., \& Suka, R. G. (2014). The Use of Small Group Discussion Technique to Increase Students'reading Comprehension. U-JET, 3(1).

Rahmat, A. (2017). Small Group Discussion Strategy Towards Students' Reading Comprehension of SMA Negeri 11 Bulukumba. Journal of English Language, Literature, and Teaching, 1(2), 28-48. https://doi.org/10.1016/S0009-2614(00)00764-8

Sumiati, C., Zulkaidah, D., \& Kaswan, K. (2019). Teaching Reading Comprehension Using Jigsaw Technique. PROJECT (Professional Journal of English Education), 2(4), 461. https://doi.org/10.22460/project.v2i4.p461-465 